INOBIS: Jurnal Inovasi Bisnis dan Manajemen Indonesia

Volume 1, Nomor 2, Maret 2018

Made Ayu Swari Oktarini; I Made Wardana

\title{
Pengaruh Perceived Ease of Use dan Perceived Enjoyment terhadap Customer Satisfaction dan Repurchase Intention
}

\author{
Made Ayu Swari Oktarini ${ }^{1}$ \\ e-mail: ayuswari20@yahoo.com ${ }^{1}$ \\ I Made Wardana ${ }^{2}$ \\ e-mail: wardana@unud.ac.id \\ ${ }^{1,2}$ Fakultas Ekonomi dan Bisnis Universitas Udayana, Bali, Indonesia
}

\begin{abstract}
Abstrak
Tujuan penelitian ini adalah untuk mengetahui Pengaruh Perceived Ease Of Use Dan Perceived Enjoyment Terhadap Customer Satisfaction Dan Repurchase Intention. Di samping itu penelitian ini juga menguji peran mediasi Customer Satisfaction hubungan antara Perceived Ease Of Use Dan Perceived Enjoyment Terhadap Repurchase Intention. Penelitian ini dilakukan pada pengguna jasa travel online $\mathrm{T}$ di Bali dengan jumlah sampel sebanyak 150 sampel. Pengumpulan data dilakukan dengan menyebarkan kuesioner. Data dianalisis dengan menggunakan pendekatan analisis jalur, dan peran mediasi diuji dengan formula Sobel. Penelitian menemukan bahwa variabel perceived ease of use dan perceived enjoyment berpengaruh positif dan signifikan terhadap customer satisfaction. Variabel perceived ease of use, perceived enjoyment dan customer satisfaction berpengaruh positif dan signifikan terhadap repurchase intention. Penelitian membuktikan semua hipotesis terbukti dan customer satisfaction secara signifikan memediasi pengaruh perceived ease of use dan perceived enjoyment terhadap repurchase intention.
\end{abstract}

Kata kunci: perceived ease of use, perceived enjoyment, customer satisfaction, repurchase intention.

\section{Pendahuluan}

Revolusi industri ke 3 dicirikan oleh berkembangnya teknologi informasi seperti internet dan teknologi digital, merubah wajah ekonomi dan bisnis yang ada di muka bumi ini. Teknologi ini menjadikan konektifitas antar manusia, antar organisasi antar perusahaan dan antar negara menjadi demikian mudahnya, sehingga segala informasi menjadi sangat cepat bisa diakses. Penyebaran akses internet yang semakin luas menjadikan internet sebagai kebutuhan yang tidak terlepas dari kehidupan sehari-hari. Dalam konteks bisnis, ketersediaan internet memberikan kesempatan pada pelaku bisnis untuk meningkatkan pemasaran produk atau jasa secara global. Penggunaan internet dalam melakukan aktivitas bisnis mengakibatkan perusahaan perlu menyesuaikan aktivitas bisnisnya dengan perkembangan teknologi yang ada (Thurau et al., 2010).

E-commerce merupakan salah satu dampak dari kemunculan internet yang saat ini dimanfaatkan oleh pelaku bisnis termasuk di Indonesia. E-commerce didefinisikan sebagai jual beli online, dimana meliputi transaksi-transaksi bisnis yang dihubungkan melalui internet (Malau, 2017:298). Banyak pengusaha yang mulai mengembangkan ataupun membangun bisnis dengan memanfaatkan e-commerce. Survei yang dilakukan Asosiasi Penyelenggara Jasa Internet Indonesia (APJII) tahun 2016 menyatakan bahwa 63,5\% pengguna internet di Indonesia pernah melakukan transaksi secara online. Hasil survey tersebut menunjukkan 
INOBIS: Jurnal Inovasi Bisnis dan Manajemen Indonesia

Volume 1, Nomor 2, Maret 2018

Made Ayu Swari Oktarini; I Made Wardana

bahwa sebagian besar masyarakat Indonesia telah memanfaatkan e-commerce untuk memenuhi kebutuhannya.

Tingginya minat belanja online masyarakat Indonesia, mendorong e-commerce tumbuh semakin pesat untuk menyediakan layanan yang diinginkan konsumen. Perilaku dan pola hidup manusia yang menghendaki segala sesuatu terpenuhi secara instan, maka munculnya e-commerce, menjadi sesuatu cara bisnis dan cara memenuhi kebutuhan menjadi sangat strategis. Kesibukan yang semakin bertambah, menyebabkan kurangnya waktu untuk melakukan kegiatan yang dianggap kurang praktis, salah satunya dalam pembelian tiket. Survei yang dilakukan Asosiasi Penyelenggara Jasa Internet Indonesia (APJII) tahun 2016 menunjukkan bahwa pembelian tiket meraih persentase tertinggi dalam belanja online yang pernah dilakukan, yaitu sebesar $25,7 \%$. Hasil survei tersebut menunjukkan antusiasme masyarakat terhadap penggunaan jasa pembelian tiket secara online. Bisnis penyedia tiket perjalanan online merupakan salah satu yang kini terus berkembang di Indonesia. Tersedianya banyak pilihan e-commerce yang menyediakan tiket perjalanan mendorong konsumen untuk membeli tiket perjalanan secara online dibandingkan mendatangi agen perjalanan secara langsung.

Untuk mengetahui jasa penyedia tiket perjalanan online yang sering digunakan oleh masyarakat di Bali, dilakukan studi pendahuluan dengan wawancara kepada 30 responden. Hasil studi pendahuluan terhadap jasa online booking tiket pesawat dan travel yang paling sering digunakan oleh masyarakat di Bali adalah Jasa Pelayanan Tiket Pesawat dan Hotel "T". Jasa Pelayanan Tiket Pesawat dan Hotel "T" merupakan perusahaan yang menyediakan situs layanan pemesanan tiket pesawat dan hotel secara online. Pemesanan tiket pesawat memiliki top brand index yang lebih tinggi dibandingkan pemesanan hotel pada situs Jasa Pelayanan Tiket Pesawat dan Hotel "T "pada tahun 2017 (topbrand-award.com). Sistem reservasi tiket yang dimiliki oleh Jasa Pelayanan Tiket Pesawat dan Hotel "T", terintegrasi dengan booking sistem dari sejumlah maskapai di Indonesia. Jasa Pelayanan Tiket Pesawat dan Hotel "T" bekerjasama dengan travel agent resmi maskapai yang sudah terpercaya untuk menerbitkan tiketnya melalui website Jasa Pelayanan Tiket Pesawat dan Hotel "T". Hal tersebut memungkinkan konsumen yang akan melakukan pemesanan tiket mendapatkan pilihan yang diinginkan dengan mudah.

Kategori online booking tiket pesawat dan travel tahun 2016 hingga 2017 menunjukkan bahwa Jasa Pelayanan Tiket Pesawat dan Hotel "T" mampu bertahan sebagai pemimpin dalam kategori tersebut. Jasa Pelayanan Tiket Pesawat dan Hotel "T" memiliki Top Brand Index (TBI) tertinggi selama 2 tahun terakhir di Indonesia, yaitu sebesar $74,8 \%$ pada tahun 2016 dan meningkat menjadi 78,5\% pada tahun 2017. Perolehan tersebut membuktikan bahwa Jasa Pelayanan Tiket Pesawat dan Hotel "T" merupakan merek yang kuat di benak pelanggan dan memiliki market share yang tinggi di Indonesia.

Untuk mampu mempertahankan posisi leader perusahaan tidak hanya memperhatikan kekuatan merek di benak konsumen dan jumlah pembelian aktual konsumen, melainkan juga perlu memperhatikan bagaimana kekuatan merek dalam mendorong minat konsumen untuk melakukan pembelian kembali di masa depan. Menumbuhkan minat konsumen untuk melakukan pembelian kembali dalam bisnis online tidaklah mudah. Minat beli ulang berkaitan dengan rencana dari konsumen untuk menggunakan kembali merek dalam suatu periode tertentu. Minat konsumen untuk melakukan pembelian kembali menjadi perhatian penting bagi Jasa Pelayanan Tiket Pesawat dan Hotel "T". Jasa Pelayanan Tiket Pesawat dan Hotel " $T$ " harus mengetahui faktor-faktor yang dapat menumbuhkan minat konsumen menggunakan jasa situs online booking Jasa Pelayanan Tiket Pesawat dan Hotel " $T$ " kembali.

Pada konteks belanja online, kemudahan penggunaan merupakan elemen yang berpengaruh positif dalam mempengaruhi konsumen melakukan pembelian kembali (Rezaei 
INOBIS: Jurnal Inovasi Bisnis dan Manajemen Indonesia

Volume 1, Nomor 2, Maret 2018

Made Ayu Swari Oktarini; I Made Wardana

dan Amin, 2013). Jasa Pelayanan Tiket Pesawat dan Hotel "T" perlu menyadari bahwa konsumen yang memahami proses pembelian pada situs lebih memiliki niat melakukan pembelian kembali dibandingkan konsumen yang tidak memahami proses pembelian dengan baik. Proses belanja online dengan prosedur yang sederhana akan meningkatkan minat konsumen untuk melakukan pembelian kembali (Adiutama dan Santika, 2014). Kemudahan penggunaan situs perlu diperhatikan untuk tampil lebih baik sebagai strategi dalam persaingan bisnis online (Chong, 2013).

Faktor lain yang dapat mempengaruhi minat konsumen dalam melakukan pembelian kembali adalah perceived enjoyment. Perceived enjoyment adalah motivasi intrinsik yang menekankan pada proses penggunaan dan mencerminkan kesenangan dan kenikmatan yang terkait dengan penggunaan sistem. Pelanggan yang telah merasakan kenikmatan dalam melakukan transaksi online memiliki kecenderungan yang lebih besar untuk melakukan pembelian kembali. Hasil penelitian yang dilakukan oleh Trisnawati dkk. (2012) menunjukkan bahwa perceived enjoyment menjadi prediktor yang konsisten dan kuat terhadap belanja online. Konsumen melakukan pembelian ulang karena bermain-main dengan internet adalah kesenangan tersendiri bagi konsumen. Ada banyak hal yang dapat minat konsumen untuk mengunjungi sebuah situs, salah satunya adalah menciptakan daya tarik situs (Baskara dan Sukaatmadja, 2016). Kesenangan ketika melihat produk-produk yang ditawarkan pada situs, kebebasan membuka situs belanja online serta pilihan produk yang beragam dapat secara signifikan mempengaruhi niat konsumen untuk melakukan pembelian kembali (Pramesthi dan Haryanto, 2013).

Hasil yang berbeda ditemukan oleh Oroh (2015) yang menyatakan bahwa perceived ease of use tidak signifikan mempengaruhi niat konsumen melakukan pembelian kembali. Banyaknya konsumen yang merasa penggunaan suatu sistem dan prosedur pembayaran yang rumit merupakan hal yang harus diperhatikan oleh pelaku bisnis online. Begitu pula penelitian yang dilakukan oleh Juniwati (2015) yang menyatakan bahwa perceived enjoyment tidak mempengaruhi konsumen dalam melakukan pembelian ulang. Hal tersebut mendukung penelitian yang dilakukan oleh Lin et al. (2010) yang menyatakan bahwa baik perceived ease of use maupun perceived enjoyment tidak memiliki pengaruh langsung yang signifikan terhadap niat membeli kembali, namun memiliki pengaruh tidak langsung melalui kepuasan pelanggan. Hal ini mencerminkan bahwa persepsi konsumen akan meningkatkan minat pembelian ulang apabila mendapatkan kepuasan ketika melakukan belanja online, karena kepuasan yang pada akhirnya akan menentukan minat konsumen melakukan pembelian kembali. Lin dan Lekhawipat (2014) menyebutkan bahwa customer satisfaction berpengaruh positif terhadap repurchase intention. Jika pengguna puas terhadap sistem, maka akan meningkatkan minat melakukan penggunaan ulang, begitupun sebaliknya (Zhou, 2013). Terciptanya kepuasan membentuk persepsi positif dari pelanggan dan kemudian akan mendorong konsumen melakukan pembelian ulang pada merek yang sama (Lu et al., 2013).

Penelitian mengenai hubungan antara perceived ease of use, customer satisfaction dan repurchase intention pernah dilakukan oleh Chen (2012) yang menyatakan bahwa membentuk persepsi kemudahan penggunaan akan dapat meningkatkan kepuasan konsumen yang akan mendorong minat konsumen melakukan pembelian berulang. Keterkaitan diantara variabel perceived enjoyment, customer satisfaction dan repurchase intention juga diperkuat oleh penelitian yang dilakukan oleh Baskara dan Sukaatmadja (2016) pada Lazada Indonesia yang menyatakan bahwa satisfaction secara signifikan memediasi pengaruh perceived enjoyment terhadap repurchase intention. Beranjak dari penelitian tersebut, penulis tertarik untuk menggabungkan kedua model dan meneliti kembali peran customer satisfaction memediasi pengaruh perceived ease of use dan perceived enjoyment terhadap repurchase 
INOBIS: Jurnal Inovasi Bisnis dan Manajemen Indonesia

Volume 1, Nomor 2, Maret 2018

Made Ayu Swari Oktarini; I Made Wardana

intention pada lokasi penelitian yang berbeda yaitu pada penggunaan Jasa Pelayanan Tiket Pesawat dan Hotel "T" di Bali.

\section{Kajian Pustaka}

TAM secara umum digunakan untuk mempelajari penerimaan sistem informasi (IS). Niat untuk menggunakan teknologi baru individu dipengaruhi perceived usefulness $(P U)$ dan perceived ease of use (PEOU), (Davis FD 1989) Untuk menjelaskan proses munculnya niat untuk menggunakan teknologi, maka perlu diberikan batasan tentang teknologi itu sendiri sebagai variabel yang akan diteliti sekaligus meneliti tentang niat untuk menggunakan teknologi tersebut (Alzubi M.M, 2017). Teknologi dapat didefinisikan sebagai, teknologi yang terlibat dalam kegiatan, pengumpulan, pengangkutan, pengambilan, penyimpanan, aksesibilitas, dan transformasi informasi untuk semua kegiatan (Boar BH, 1997).

Perceived ease of use didefinisikan sebagai tingkat kepercayaan individu yang menggunakan teknologi baru akan bebas dari usaha yang keras (Davis, 1989). Menurut Wahyuningtyas dan Widiastuti (2015) perceived ease of use (persepsi kemudahan) akan berdampak kepada perilaku, yaitu semakin tinggi persepsi seseorang tentang kemudahan dalam menggunakan sistem, semakin tinggi pula tingkat pemanfaatan teknologi tersebut.

Perceived enjoyment (kenikmatan) adalah salah satu jenis kebutuhan yang berdasarkan arah dari motivasi yang bersifat subjektif dan experiental, yang berarti bahwa konsumen akan mengandalkan suatu produk atau melakukan kegiatan tertentu untuk menemukan kebutuhan mereka sebagai pemberi kegembiraan, kepercayaan diri, khayalan atau tanggapan emosional dan lainnya (Utami, 2010:49). Adanya kenikmatan yang dirasakan dapat menyebabkan para pelanggan akan menyukai bahwa belanja online itu menyenangkan, tetapi jika belanja online itu kurang mendapatkan kenikmatan dari pelanggan, mereka bisa saja berpikir bahwa belanja online tidaklah berguna (Trisnawati dkk., 2012).

Customer satisfaction (kepuasan) adalah perasaan senang atau kecewa seseorang yang timbul karena membandingkan kinerja yang dipersepsikan produk atau hasil terhadap ekspektasi mereka. Jika kinerja gagal memenuhi ekspektasi, pelanggan akan tidak puas. Jika kinerja sesuai dengan ekspektasi, pelanggan akan sangat puas atau senang (Kotler dan Keller, 2009:138). Kepuasan konsumen yang tinggi merupakan indikator terbaik dari keuntungan masa depan perusahaan dan secara luas ditandai sebagai evaluasi pasca pembelian (Cengiz, 2010).

Repurchase merupakan kecenderungan perilaku membeli dari konsumen pada suatu produk barang atau jasa yang dilakukan secara berulang dalam jangka waktu tertentu dan secara aktif menyukai dan mempunyai sikap positif terhadap suatu produk barang atau jasa, didasarkan pada pengalaman yang telah dilakukan dimasa lampau (Suryana dan Dasuki, 2013). Repurchase intention timbul setelah konsumen mencoba produk tersebut dan kemudian timbul rasa suka atau tidak suka terhadap produk tersebut (Abdullah, 2003:25). Menurut Nurhayati (2012) repurchase intention adalah keinginan dan tindakan konsumen untuk membeli ulang suatu produk, karena adanya kepuasan yang diterima sesuai yang dinginkan dari suatu produk. Merek yang sudah melekat dalam hati pelanggan akan menyebabkan pelanggan melanjutkan pembelian atau pembelian ulang. Repurchase intention juga dapat digunakan untuk memprediksi apakah konsumen bisa menjadi pelanggan jangka panjang dan membawa keuntungan yang stabil bagi perusahaan atau sebaliknya (Meng et al., 2011).

Amin et al. (2014) mengemukakan bahwa perceived ease of use berpengaruh positif dan signifikan terhadap customer satisfaction. Kemudahan dalam mempelajari dan menggunakan suatu sistem secara positif dapat meningkatkan kepuasan konsumen. Hasil 
INOBIS: Jurnal Inovasi Bisnis dan Manajemen Indonesia

Volume 1, Nomor 2, Maret 2018

Made Ayu Swari Oktarini; I Made Wardana

serupa ditemukan oleh penelitian yang dilakukan Hidayat dan Winarno (2014) yang menyatakan bahwa kepuasan konsumen secara positif dan signifikan dipengaruhi oleh kemudahan penggunaan. Penelitian lain yang dilakukan Tandon et al. (2016) menemukan hasil serupa bahwa perceived ease of use berpengaruh positif terhadap customer satisfaction. Hal tersebut mengindikasikan bahwa semakin besar kemudahan yang dirasakan saat melakukan pembelian akan meningkatkan kepuasan konsumen dalam berbelanja online. Berdasarkan penelitian-penelitian tersebut maka dapat digambarkan kerangka konsep dan disusun hipotesis sebagai berikut:

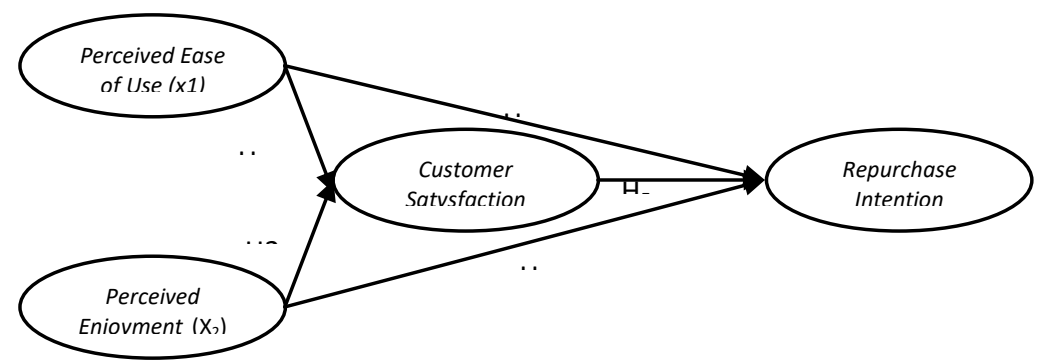

Gambar 1 Kerangka Konseptual

$\mathrm{H}_{1}$ : Perceived ease of use berpengaruh positif dan signifikan terhadap customer satisfaction

Juniwati (2015) mengemukakan bahwa perceived enjoyment berpengaruh positif dan signifikan terhadap customer satisfaction. Kesenangan atau kenikmatan yang dirasakan saat melakukan pembelian memiliki pengaruh yang penting pada perilaku pelanggan. Penelitian yang dilakukan oleh Wen et al. (2011) menyatakan bahwa penampilan website yang menarik merupakan salah satu elemen perceived enjoyment yang akan meningkatkan kepuasan pelanggan secara positif dan signifikan dalam melakukan pembelian. Baskara dan Sukaatmadja (2016) mengungkapkan bahwa kualitas situs serta desain website yang menawarkan berbagai produk serta harga yang beragam dapat menarik konsumen untuk mengunjunginya. Kesenangan atau kenikmatan yang dirasakan pengguna dalam melakukan penjelajahan website secara langsung dapat meningkatkan kepuasan konsumen. (Fang et al., 2016). Berdasarkan penelitian-penelitian tersebut maka dapat disusun hipotesis sebagai berikut:

$\mathrm{H}_{2}$ : Perceived enjoyment berpengaruh positif dan signifikan terhadap customer satisfaction

Rezaei dan Amin (2013) menyatakan kemudahan dalam penggunaan suatu sistem akan secara positif dan signifikan dapat meningkatkan minat konsumen untuk melakukan pembelian ulang. Penelitian yang dilakukan Juniwati (2015) menunjukkan bahwa sangat penting bagi pemasar untuk memperhatikan kemudahan dalam prosedur pembelian suatu produk. Semakin mudah prosedur pembelian dinilai dapat meningkatkan ketertarikan konsumen untuk melakukan pembelian ulang. Sejalan dengan penelitian yang ada, hasil serupa diungkapkan oleh Chong (2013), Adiutama dan Santika (2014) serta Apriyani dan Suharti (2017) yang menyatakan bahwa perceived ease of use berpengaruh positif dan signifikan terhadap repurchase intention. Berdasarkan penelitian-penelitian tersebut maka dapat disusun hipotesis sebagai berikut:

$\mathrm{H}_{3}$ : Perceived ease of use berpengaruh positif dan signifikan terhadap repurchase intention 
INOBIS: Jurnal Inovasi Bisnis dan Manajemen Indonesia

Volume 1, Nomor 2, Maret 2018

Made Ayu Swari Oktarini; I Made Wardana

Penelitian yang dilakukan oleh Trisnawati dkk. (2012) menyatakan bahwa desain situs yang menarik dan pemberian informasi yang baik saat melakukan belanja online merupakan elemen dari perceived enjoyment yang memiliki pengaruh positif dan signifikan dalam meningkatkan keinginan konsumen melakukan pembelian kembali (repurchase intention). Baskara dan Sukaatmadja (2016) menunjukkan bahwa untuk memperoleh efek yang positif dan signifikan pada minat pembelian kembali, maka perusahaan harus mampu memberikan kenyamanan serta situs yang menarik untuk dikunjungi. Hasil penelitian yang dilakukan Pramesthi dan Haryanto (2013) mengungkapkan bahwa kesenangan yang dirasakan konsumen saat mengunjungi situs belanja online dapat mempengaruhi minat konsumen untuk melakukan pembelian kembali. Penelitian yang dilakukan Tambunan dan Handayani (2017) menunjukkan hasil serupa bahwa perceived enjoyment berpengaruh positif dan signifikan terhadap repurchase intention. Berdasarkan penelitian-penelitian tersebut maka dapat disusun hipotesis sebagai berikut:

$\mathrm{H}_{4}$ : Perceived enjoyment berpengaruh positif dan signifikan terhadap repurchase intention

Lin dan Lekhawipat (2014) mengemukakan bahwa customer satisfaction memainkan peranan yang penting dalam mempengaruhi minat pembelian kembali (repurchase intention). Konsumen yang merasa puas cenderung memiliki minat melakukan pembelian kembali dibandingkan dengan konsumen yang tidak puas. Semakin tinggi tingkat kepuasan konsumen maka semakin tinggi pula niat konsumen melakukan pembelian kembali (Zhou, 2013). Penelitian lain yang dilakukan oleh Baskara dan Sukaatmadja (2016) menunjukkan hal serupa yang menunjukkan bahwa satisfaction berpengaruh positif dan signifikan terhadap repurchase intention. Berdasarkan penelitian-penelitian tersebut maka dapat disusun hipotesis sebagai berikut:

$\mathrm{H}_{5}$ : Customer satisfaction berpengaruh positif dan signifikan terhadap repurchase intention

Penelitian yang dilakukan Oroh dkk. (2015) menyatakan bahwa perceived ease of use tidak signifikan terhadap repurchase intention. Penelitian yang dilakukan Lin et al. (2010) menyatakan hal serupa bahwa perceived ease of use tidak memiliki pengaruh langsung yang signifikan terhadap repurchase intention, namun menunjukkan pengaruh tidak langsung melalui customer satisfaction. Indikasi ini juga semakin diperkuat oleh penelitian Chen (2012) yang menyatakan bahwa penting bagi perusahaan untuk mampu meningkatkan layanan untuk konsumen salah satunya adalah kemudahaan penggunan sistem. Kemudahan penggunaan dinilai dapat meningkatkan kepuasan konsumen sehingga berniat melakukan pembelian ulang. Berdasarkan penelitian-penelitian tersebut maka dapat disusun hipotesis sebagai berikut:

$\mathrm{H}_{6}$ : Customer satisfaction mampu secara signifikan memediasi perceived ease of use terhadap repurchase intention

Penelitian yang dilakukan oleh Juniwati (2015) mengemukakan bahwa perceived enjoyment tidak mempengaruhi konsumen dalam pembelian ulang. Lin et al. (2010) menunjukkan bahwa perceived enjoyment memiliki pengaruh tidak langsung terhadap repurchase intention dan dalam pengaruhnya sepenuhnya dimediasi oleh customer satisfaction. Hubungan ini diperkuat dengan penelitian yang dilakukan oleh Baskara dan Sukaatmadja (2016) yang menunjukkan bahwa satisfaction berperan secara signifikan memediasi pengaruh perceived enjoyment terhadap repurchase intention. Hal tersebut berarti semakin besar perceived enjoyment yang dirasakan, maka akan semakin tinggi juga kepuasan konsumen, dimana hal tersebut akan mampu meningkatkan minat konsumen untuk 
INOBIS: Jurnal Inovasi Bisnis dan Manajemen Indonesia

Volume 1, Nomor 2, Maret 2018

Made Ayu Swari Oktarini; I Made Wardana

melakukan pembelian kembali. Berdasarkan penelitian-penelitian tersebut maka dapat disusun hipotesis sebagai berikut:

$\mathrm{H}_{7}$ : Customer satisfaction mampu memediasi secara signifikan perceived enjoyment terhadap repurchase intention

\section{Metode Penelitian}

Penelitian ini adalah jenis penelitian kuantitatif, yang merupakan penelitian bersifat asosiatif. Penelitian ini dilakukan di Bali Provinsi Bali, dengan pertimbangan Bali merupakan pusat kegiatan ekonomi pariwisata, diyakini memiliki masyarakat dengan kesadaran teknologi yang tinggi, untuk menggunakan situs Jasa Pelayanan Tiket Pesawat dan Hotel "T". Jumlah sampel yang digunakan pada penelitian ini adalah 150 responden. Untuk menguji hipotesis data dianalisis menggunakan teknik analisis jalur (Path Analysis), dan menguji peran mediasi menggunakan teknik uji Sobel.

\section{Hasil dan Pembahasan}

\section{Uji Validitas Instrumen}

Uji validitas bertujuan untuk menilai instrumen yang digunakan telah tepat untuk mengukur indikator dalam penelitian. Pernyataan dalam kuesioner dikatakan valid jika koefisien korelasi $\geq 0,3$. Hasil uji validitas intrumen variabel disajikan dalam Tabel 1 sebagai berikut:

Tabel 1 Hasil Uji Validitas

\begin{tabular}{|c|c|c|c|c|}
\hline No. & Variabel & Indikator & $\begin{array}{l}\text { Koefisien } \\
\text { Korelasi }\end{array}$ & Ket. \\
\hline & & Fleksibel & 0,89 & Valid \\
\hline 1. & $\begin{array}{l}\text { Perceived } \\
\text { Ease of Use }\end{array}$ & $\begin{array}{l}\text { Mudah dipelajari } \\
\text { Prosedur jelas }\end{array}$ & $\begin{array}{l}0,87 \\
0,87\end{array}$ & $\begin{array}{l}\text { Valid } \\
\text { Valid }\end{array}$ \\
\hline 2. & $\begin{array}{l}\text { Perceived } \\
\text { Enjoyment }\end{array}$ & $\begin{array}{l}\text { Kenyamanan } \\
\text { bertransaksi } \\
\text { Desain menarik } \\
\text { Kesenangan }\end{array}$ & $\begin{array}{l}0,88 \\
0,81\end{array}$ & $\begin{array}{l}\text { Valid } \\
\text { Valid }\end{array}$ \\
\hline 3. & $\begin{array}{c}\text { Customer } \\
\text { Satisfaction }\end{array}$ & $\begin{array}{l}\text { Kepuasan secara } \\
\text { keseluruhan } \\
\text { Konfirmasi harapan } \\
\text { Pilihan yang tepat }\end{array}$ & $\begin{array}{l}0,88 \\
0,92 \\
0,79\end{array}$ & $\begin{array}{l}\text { Valid } \\
\text { Valid } \\
\text { Valid }\end{array}$ \\
\hline 4. & $\begin{array}{c}\text { Repurchase } \\
\text { Intention }\end{array}$ & $\begin{array}{l}\text { Frekuensi pembelian } \\
\text { Komitmen pelanggan } \\
\text { Rekomendasi positif }\end{array}$ & $\begin{array}{l}0,96 \\
0,94\end{array}$ & $\begin{array}{l}\text { Valid } \\
\text { Valid }\end{array}$ \\
\hline
\end{tabular}

Tabel 1 menunjukan nilai koefisien korelasi dari masing-masing instrumen lebih besar 0,3 sehingga seluruh intrumen yang digunakan dapat dikatakan valid. 
INOBIS: Jurnal Inovasi Bisnis dan Manajemen Indonesia

Volume 1, Nomor 2, Maret 2018

Made Ayu Swari Oktarini; I Made Wardana

\section{Reliabilitas Instrumen}

Selanjutnya dilakukan uji reliabilitas untuk mengukur konsistensi alat ukur yang digunakan. Suatu intrumen dapat dikatakan raliabel apabila koefisien alpha cronbach $\geq 0,6$. Hasil pengukuran reliabilitas masing-masing variabel disajikan dalam Tabel 2 sebagai berikut.

Tabel 2.

Hasil Uji Reabilitas

\begin{tabular}{cccc}
\hline No. & \multicolumn{1}{c}{ Variabel } & Cronbach's Alpha & Keterangan \\
\hline 1. & Perceived Ease of Use & 0,85 & Reliabel \\
2. & Perceived Enjoyment & 0,81 & Reliabel \\
3. & Customer Satisfaction & 0,83 & Reliabel \\
4. & Repurchase Intention & 0,92 & Reliabel \\
\hline
\end{tabular}

Sumber: data diolah, 2017

Tabel 2 menunjukan nilai koefisien alpha cronbach $\geq 0,6$. dari masing-masing instrumen dan instrumen penelitian dapat dikatakan reliabel.

\section{Uji Hipotesis}

Hipotesis penelitian diuji dengan menggunakan teknik Analisis Jalur (Path Analysis). Hasil pengujian hipotesis penelitian dirangkum dalam Tabel 3 sebagai berikut:

Tabel 3

Analisis Jalur Variabel Penelitian

\begin{tabular}{ccccc}
\hline No. & $\begin{array}{c}\text { Pengaruh } \\
\text { Variabel }\end{array}$ & $\begin{array}{c}\text { T } \\
\text { Statistik }\end{array}$ & Sig & Keterangan \\
\hline 1. & $X 1 \rightarrow Y 1$ & 4.503 & 0.01 & \\
2. & $X 2 \rightarrow Y 1$ & 6.060 & 0.00 & Signifikan \\
3. & $X 1 \rightarrow Y 2$ & 3.543 & 0.02 & Signifikan \\
4. & $X 2 \rightarrow Y 2$ & 2.021 & 0.04 & Signifikan \\
5. & $Y 1 \rightarrow Y 2$ & 2.554 & 0.03 & Signifikan \\
\hline
\end{tabular}

Sumber: Data diolah, 2017

Tabel 3 menunjukkan bahwa semua hipotesis yang diajukan dan dianalisis menggunakan analisis jalur diterima atau terbukti. Hasil penelitian ini mendukung teori yang telah diajukan.

Tahap berikutnya dilakukan uji Sobel untuk mengukur peran mediasi customer satisfaction pada hubungan perceived ease of use terhadap repurchase intention. Berdasarkan perhitungan yang telah dilakukan, diperoleh nilai $\mathrm{Z}$ sebesar 2,4562 >1,96 ini berarti variabel customer satisfaction secara signifikan memediasi perceived ease of use terhadap repurchase intention. Selanjutnya Berdasarkan perhitungan yang telah dilakukan ternyata variabel customer satisfaction juga dinilai secara signifikan memediasi perceived enjoyment terhadap repurchase intention, berdasarkan nilai $\mathrm{Z}$ sebesar 2,6192 > 1,96 
INOBIS: Jurnal Inovasi Bisnis dan Manajemen Indonesia

Volume 1, Nomor 2, Maret 2018

Made Ayu Swari Oktarini; I Made Wardana

\section{Simpulan}

Berdasarkan hasil uji hipotesis, dapat disimpulkan bahwa perceived ease of use berpengaruh positif dan signifikan terhadap customer satisfaction, dengan demikian semakin baik perceived ease of use pada penggunaan situs Jasa Pelayanan Tiket Pesawat dan Hotel "T", maka customer satisfaction akan semakin meningkat. Perceived enjoyment berpengaruh positif dan signifikan terhadap customer satisfaction. Ini berarti bahwa semakin baik Perceived enjoyment maka customer satisfaction akan semakin meningkat. Perceived ease of use berpengaruh positif dan signifikan terhadap repurchase intention. Ini berarti semakin baik Perceived ease of use maka semakin baik repurchase intention. Perceived enjoyment berpengaruh positif dan signifikan terhadap repurchase intention. Ini berarti semakin baik perceived enjoyment pada penggunaan situs Jasa Pelayanan Tiket Pesawat dan Hotel " $T$ ", maka repurchase intention terhadap situs ini pun semakin meningkat. Customer satisfaction berpengaruh positif dan signifikan terhadap repurchase intention, dengan demikian semakin tinggi customer satisfaction pada penggunaan situs Jasa Pelayanan Tiket Pesawat dan Hotel "T", maka repurchase intention terhadap situs ini pun semakin meningkat.

Customer satisfaction mampu memediasi perceived ease of use dengan repurchase intention secara positif dan signifikan. Dengan demikian customer satisfaction perlu diciptakan untuk meningkatkan pengaruh perceived ease of use terhadap repurchase intention penggunaan situs Jasa Pelayanan Tiket Pesawat dan Hotel "T". Customer satisfaction mampu memediasi perceived enjoyment dengan repurchase intention secara positif dan signifikan. Dengan demikian customer satisfaction perlu diciptakan untuk meningkatkan pengaruh perceived enjoyment terhadap repurchase intention penggunaan situs Jasa Pelayanan Tiket Pesawat dan Hotel "T"

Rekomendasi yang dapat diberikan adalah perusahaan perlu melakukan evaluasi secara berkala terhadap prosedur yang ada pada situs. Kemajuan teknologi menuntut adanya pembaruan fitur dan harus diimbangi dengan diterbitkannya prosedur penggunaannya, sehingga akan dapat mempermudah dan meningkatkan kepuasan konsumen dalam penggunaan situs Jasa Pelayanan Tiket Pesawat dan Hotel "T".

\section{Daftar Pustaka}

Alzubi, M.M., 2017. The Mediating Role Of Awareness In The Intention To Use Internet Banking Among SmeS In Yemen, Journal of Internet Banking and Commerce, August 2017, vol. 22, no. 2.

Abdullah, Thamrin. 2003. Manajemen Pemasaran. Jakarta: PT. Rajawali Pers.

Adiutama, I Made Rendy Wicaksana dan I Wayan Santika. 2014. Pengaruh Persepsi Kemudahan Penggunaaan, Kegunaan yang dirasakan, dan tingkat pendidikan terhadap niat berbelanja kembali pada situs tokobagus.com. E-Jurnal Manajemen Unud, 3 (10):2815-2831.

Amin, Muslim. Sajad Rezei and Maryam Abolghasemi. 2014. User satisfaction with mobile websites: the impact of perceived usefulness (PU), perceived ease of use (PEOU) and trust. Nankai Business Review International, 5 (3):258-274.

Apriyani, Nuri dan Suharti. 2017. Analisis Pengaruh Persepsi Kebermanfaatan, Persepsi Kemudahan dan Kepercayaan Terhadap Minat Beli Ulang Pengguna Smartphone Xiaomi. Jurnal Manajemen Dewantara, 1 (1):21-34.

Asosiasi Penyelenggara Jasa Internet Indonesia (APJII). 2016. Penetrasi \& Perilaku Pengguna Internet Indonesia Survey 2016. Jakarta: APJII. 
INOBIS: Jurnal Inovasi Bisnis dan Manajemen Indonesia

Volume 1, Nomor 2, Maret 2018

Made Ayu Swari Oktarini; I Made Wardana

Baskara, I Made Arya dan I Putu Gde Sukaatmadja. 2016. Pengaruh Online Trust dan Perceived Enjoyment Terhadap Online Shopping Satisfaction dan Repurchase Intention Lazada Indonesia. E-Jurnal Manajemen Unud, 5 (11):7214-7244.

Boar BH (1997) Strategic thinking for information technology: How to build the IT organization for the information age. John Wiley and Sons, Inc.

Cengiz, Emrah. 2010. Measuring Customer Satisfaction: must or not?. Journal of Naval Science and Enginering, 6(2):76-88.

Chen, Yue-Yang. 2012. Why Do Consumers Go Internet Shopping Again? Understanding the Antecedents of Repurchase Intention. Journal of Organizational Computing and Electronic Commerce, 22 (1):38-63.

Chong, A.Y.L. 2013. Understanding mobile commerce continuance intention: An empirical analysis of Chinese consumers. The Journal of Computer Information Systems, 53(4):22-30.

Davis, F. D. 1989. Perceived Usefulness, Perceived Ease of Use, and User Acceptance of Information Technology, MIS Quarterly, 13(3):319-340.

Fang, Jiaming, Yunfei Shao and Chao Wen. 2016. Transactional quality, relational quality, and consumer e-loyalty: Evidence from SEM and fsQCA. International Journal of Information Management, 36 (6):1205-1217.

Ghozali, Imam. 2013. Aplikasi Analisis Multivariate dengan Program IBM SPSS 2.1, Edisi. Ketujuh, Semarang: Badan Penerbit UNDIP.

Haryanto, Agus Tri. 2017. Akuisisi Tiket.com, Blibli: Biar Traveloka Tidak Kesepian www.detik.com (diunduh tanggal 20 Juni 2017)

Hidayat, Maulana dan Wing Wahyu Winarno. 2014. Evaluasi Kepuasan Pengguna Wi-fi Dengan Metode Importance-Performance Analysis dan Customer Satisfaction Index (Studi Kasus UGM-Hotspot, Fakultas Teknik, Universitas Gadjah Mada). Tesis Fakultas Teknik Universitas Gadjah Mada.

Juniwati. 2015. Pengaruh Ease of Use, Enjoyment dan Trust terhadap Repurchase Intention dengan Customer Satisfaction Sebagai Variabel Intervening pada Belanja Online (Studi pada Mahasiswa Universitas Tanjungpura Pontianak). Jurnal Ekonomi Bisnis dan Kewirausahaan, 4 (1):140-156.

Kotler, Philip dan Gary Amstrong. 2001. Prinsip-Prinsip Pemasaran. Jakarta: Erlangga.

Kotler, Philip dan Kevin Lane Keller. 2009. Manajemen Pemasaran. Jakarta: Erlangga.

Lin, Chwen-Yea., Kwoting Fang and Chien-Chung Tu. 2010. Predicting Consumer Repurchase Intentions to Shop Online. Journal of Computers, 5(10):1527-1533.

Lin, Chinho and Watcharee Lekhawipat. 2014. Factors affecting online repurchase intention. Industrial Management \& Data Systems, 114 (4):597-611.

Lu, L.C., Chang H.H and Yu S.T. 2013. Online Shoppers Perceptions of E-retailers Ethics, Cultural Orientation and Loyalty An Exploratory Study in Taiwan. Internet Research, 23 (1):47-68.

Meng, S.M., Gin S.L. and Shih H.Y. 2011. The Relationship of Cruise Image, Perceived Value, Satisfaction and Post-Purchase Behavioral Intention on Taiwanese Tourist. African Journal of Business Management, 5(1):19-29.

Nurhayati dan Wahyu Wijaya Murti. 2012. Analisis Faktor-Saktor Yang Mempengaruhi Minat Beli Ulang Masyarakat Terhadap Produk Handphone. Value Added, 8 (2):4762.

Nurlinda, R.A. 2013. Pengaruh Customer Satisfaction Strategy Terhadap Peningkatan Kepuasan Konsumen. Forum Ilmiah, 10(2):172-181. 
INOBIS: Jurnal Inovasi Bisnis dan Manajemen Indonesia

Volume 1, Nomor 2, Maret 2018

Made Ayu Swari Oktarini; I Made Wardana

Oroh, Cindy Regina., David P.E.S. dan Farlane S.R. 2015. The Influence of Perceived Ease of Use, Perceived Usefulness and Trust on Repurchase Intention of Lion Air E-Ticket. Jurnal Berkala Ilmiah Efisiensi, 15(5):367-376

Parastanti, G.P., Srikandi, K. dan Kadarisman, H. 2014. Pengaruh Prior Online Purchase Experience Terhadap Trust dan Online Repurchase Intention. Jurnal Administrasi Bisnis (JAB), 16 (1):1-7.

Pramesthi, Febriana dan Haryanto. 2013. Efek Perceived Ease of Use dan Confirmation Terhadap Anteseden Online Repurchase Intention. Fokus Manajerial, 12 (1):81-91.

Puspitasari, Diana. 2006. Analisis Pengaruh Persepsi Kualitas dan Kepuasan Pelanggan Terhadap Minat Beli Ulang. Tesis Universitas Diponegoro.

Riduwan dan Engkos Achmad Kuncoro. 2011. Cara Menggunakan dan Memaknai Analisis Jalur (Path Analysis). Bandung: Alfabeta.

Rezaei, S and Amin, M. 2013. Exploring Online Repurchase Behavioural Intention of University Students in Malaysia. Journal for Global Business Advancement, 6 (2):92119.

Sugiyono. 2014. Metode Penelitian Bisnis (Pendekatan Kuantitatif, Kualitatif, dan R\&D). Bandung: Alfabeta.

Suharso. 2010. Model Analisis Kuantitatif "TEV”. Jakarta: Indeks.

Suryana, Popo dan Eliyandi S. D. 2013. Analisis Faktor Yang Mempengaruhi Keputusan Pembelian dan Implikasinya Pada Minat Beli Ulang. Trikonomika, 12 (2):190-200.

Tambunan, Samuel dan Wiwik Handayani. 2017. Minat Beli Ulang Kartu Perdana Nomor Cantik Simpati (Studi Dicomtech Shop Surabaya). Manajemen Bisnis, 1 (1):85-92.

Tandon, Urvashi, Ravi Kiran and Ash N.S. 2016. Analysing the Complexities of Website Functionality, Perceived Ease of Use and Perceived Usefullness on Customer Satisfaction of Online Shoppers in India. International Journal of Electronic Marketing and Retailing, 7 (2):115-140

Thurau, T.H., Edward C. Malthouse, Christian F., Sonja G., Lara L., Arvind R. and Bernd S. 2010. The Impact of New Media on Customer Relationships. Journal of Service Research, 13 (3):311-330.

Top Brand Award. 2017. Top Brand Kategori Situs Online Booking Tiket Pesawat dan Travel. www.topbrand-award.com (diunduh tanggal 20 Mei 2017)

Top Brand Award. 2017. Top Brand Criteria. www.topbrand-award.com (diunduh pada 20 Mei 2017)

Trisnawati, Ella, Agus Suroso dan Untung Kumorohadi. 2012. Analisis dari faktor-faktor kunci niat pembelian kembali secara online (Studi Kasus pada Konsumen Fesh Shop). Jurnal Bisnis dan Ekonomi (JBE), 19 (2):126-141.

Utama, S.M. 2010. Aplikasi Analisis Kuantitatif Edisi Ketiga. Denpasar: Sastra Utama.

Utami, Christina Whidya. 2010. Manajemen Ritel (Strategi dan Implementasi Operasional Bisnis Ritel Modern di Indonesia). Jakarta: Salemba Empat.

Wahyuningtyas, Yunita Fitri dan Dyah Ayu Widiastuti. 2015. Analisis Pengaruh Persepsi Risiko, Kemudahan dan Manfaat Terhadap Keputusan Pembelian Secara Online (Studi Kasus Pada Konsumen Barang Fashion di Facebook). Jurnal Kajian Bisnis, 23 (2):112-120.

Wen, C., Victor, R.P and Chenyan, X. 2011. An Integrated Model for Costumer Online Repurchase Intention. Journal of Computer Information Systems, 52 (1):14-23.

Zhou, Tao. 2013. An Empirical Examination of Continuance Intention of Mobile Payment Services. Decision Support System, 54 (2):1085-1091. 